\title{
Production and Technology of Iron and Steel in Japan during 2001
}

\author{
Masayuki HANMYO \\ Former Chief of Production and Technology Division, The Iron and Steel Institute of Japan, Kanda-Tsukasacho, Chiyoda-ku, \\ Tokyo 101-0048 Japan.
}

\section{The Economic Circumstance of the Japanese Iron and Steel Industry}

The outlook for year 2001 was projected to be extremely severe, but in reality, the recession surpassed everyone's expectation, and the economy seemed to have entered a deflation spiral, and the actual economic growth rate fell into negative. In Japan, because of the government's attempt at processing bad debts to push forward structural reform, movement toward reduction or termination of public works, collapse of bubble for the information technology (IT) related business which encouraged public sector facilities investment in 2000, and undermining of electric and automobile industries due to shift of production mainly to China, the circumstance has fallen into long-term stagnation of domestic demand, despite collaboration, merging, and restructuring efforts of the companies. Due to substantial slowdown of the United States economic growth and safeguard measures regarding Trade Act 201, exports to the United States were poor. The Asian countries which maintained relatively good performance in 2000, particularly the four NIES countries including Korea, Taiwan, Hong Kong, and Singapore were affected by their high dependency on IT related exports, so the slowdown of the economy due to IT recession hit hard, and exports from Japan did not increase. Moreover, the terrorist attack against the United States in September resulted in accelerating the worldwide recession.

In terms of employment, the unemployment rate was $5.0 \%$, which was higher than 1999 and 2000 when the worst figures were recorded since 1953 when the survey was started, and the rate entered the $5 \%$ level for the first time. Seen by month, the unemployment rate was $5.3 \%$ in September, 5.4\% in October, 5.5\% in November, and 5.6\% in December, and the worst records were renewed consecutively for four months, and it seems that the situation may worsen further. The number of unemployed was 3.4 million workers, which was the worst figure surpassing 3 million workers for three years in row, and the severe condition continues. The number of employed was 64.12 million workers, which was 0.34 million less workers compared to 2000 , and this was four years consecutive decrease. By business, the numbers of workers of the service industry increased significantly following 2000, while that of the manufacturing industry declined nine years consecutively and that of the construction industry marked four years consecutive decline.

For investments, facilities investment by private sector turned positive compared to previous year due to the strong lead of the IT industry in 2000, but IT related investments declined in 2001, and personal consumption and home investments declined compared to previous year due to poor employment and income environment. For public investments, the effect of supplementary budget was limited and investments decreased sharply.

Looking at the supply and demand of iron and steel in the above circumstances, domestic consumption of steel products for both construction and manufacture, which were areas of major demand, declined dramatically. In construction field, the main reasons for the decline were: decrease in public construction due to restraint of public investment; decrease in number of new houses constructed due to reduced home ownership; and decrease in nonresidential construction such as factory buildings and stores. In manufacturing field, good performance was seen only in tanker shipbuilding, and all others including automobiles, electricities, and machineries declined due to deceleration of the United States economy, expansion of overseas production, and slowdown of domestic consumption.

Contrary to the initial projection that there would be significant decline, steel product export was positive compared to the year 2000, supported by the increase in pig iron and half-products for mainly Southeast Asia, despite some deterioration of supply and demand circumstance in overseas market. Steel product import showed significant decrease of over $20 \%$ compared to 2000 , due to increased stock and price decline in Japan, and also particularly due to fluctuation in exchange rate (lower yen) in the latter half of 2001.

In terms of production, the crude steel production almost matched the initial projection of over 100 million ton, and it was 102.86 million ton or 3.58 million ton $(3.4 \%)$ decrease compared to 2000 , which was decrease for the first time in three years, but the 100 million level was maintained two years consecutively. By furnace types, L.D. converter was 74.44 million ton or $1.8 \%$ decreased, and electric furnace was 28.42 million ton or $7.3 \%$ decrease. Since the decrease of electric furnace steel was significant, the electric furnace ratio was $27.6 \%$, a five years consecutive decrease. By steel types, ordinary steel was 83.94 million ton or $4.1 \%$ decrease, and special steel was 18.92 million ton or $0.3 \%$ increase.

The production of hot-rolled ordinary steel products was 78.79 million ton or 4.25 million ton $(5.1 \%)$ decrease compared to 2000, so it fell to the 70 million ton level. By product types, heavy steel-medium plates alone showed good 
Table 1. Transition of iron, steel and steel main goods production (unit: 1000 tons)

\begin{tabular}{|c|c|c|c|c|c|c|c|c|c|}
\hline & \multirow{2}{*}{$\begin{array}{c}1998 \\
\text { Total } \\
\end{array}$} & \multirow{2}{*}{$\begin{array}{c}1999 \\
\text { Total } \\
\end{array}$} & \multirow{2}{*}{$\begin{array}{l}2000 \\
\text { Total } \\
\end{array}$} & \multirow{2}{*}{$\begin{array}{l}2001 \\
\text { Total } \\
\end{array}$} & \multicolumn{4}{|c|}{2001} & \multirow{2}{*}{$\begin{array}{c}(2001-2000) \\
(\%)\end{array}$} \\
\hline & & & & & Jan.-March & April-June & July-Sept. & Oct.-Dec. & \\
\hline Crude steel & 93,548 & 94,192 & 106,444 & 102,863 & 25,857 & 26,376 & 25,826 & 24,804 & -3.4 \\
\hline By B.O.F & 63,716 & 65,452 & 75,784 & 74,442 & 18,654 & 19,002 & 19,150 & 17,636 & -1.8 \\
\hline By E.A.F & 29,832 & 28,740 & 30,660 & 28,421 & 7,203 & 7,374 & 6,675 & 7,169 & -7.3 \\
\hline Pig iron by B.F & 74,979 & 74,518 & 81,068 & 78,833 & 19,262 & 19,960 & 20,414 & 19,197 & -2.8 \\
\hline Hot-rolled ordinary steel & 73,379 & 73,221 & 83,044 & 78,789 & 20,033 & 19,647 & 19,774 & 19,335 & -5.1 \\
\hline Large H shapes & 7,989 & 6,652 & 7,235 & 6,206 & 1,620 & 1,509 & 1,508 & 1,569 & -14.2 \\
\hline Medium and Small shapes & 1,699 & 1,636 & 1,752 & 1,558 & 418 & 393 & 345 & 402 & -11.1 \\
\hline Small bar & 11,881 & 11,850 & 12,247 & 11,908 & 2,939 & 3,045 & 2,938 & 2,986 & -2.8 \\
\hline Wire & 2,864 & 2,896 & 2,736 & 2,401 & 641 & 598 & 574 & 588 & -12.2 \\
\hline Medium \& Heavy plate & 8,246 & 7,629 & 8,618 & 9,301 & 2,341 & 2,226 & 2,342 & 2,392 & 7.9 \\
\hline Wide hot strip & 35,090 & 36,873 & 44,529 & 41,724 & 10,646 & 10,519 & 10,702 & 9,857 & -6.3 \\
\hline Hot-rolled special steel & 14,774 & 14,224 & 15,748 & 15,828 & 4,173 & 3,952 & 3,870 & 3,833 & 0.5 \\
\hline Structure & 5,541 & 5,430 & 6,209 & 6,087 & 1,627 & 1,467 & 1,483 & 1,510 & -2.0 \\
\hline Stainless steel & 2,767 & 2,651 & 3,021 & 3,138 & 806 & 804 & 788 & 740 & 3.9 \\
\hline Spring and bearing & 996 & 1,008 & 1,172 & 1,009 & 281 & 250 & 242 & 236 & -13.9 \\
\hline
\end{tabular}

performance of $7.9 \%$ increase, while section-wire-rod products such as shapes and wire rods showed double-digit decrease and wide strip, which is main product, decreased $6.3 \%$, and all others fell negative compared to 2000 .

On the other hand, production of hot-rolled special steel products was 15.83 million tons or 0.08 million tons $(0.5 \%)$ increase compared to 2000, and maintained the 15 million ton level two years consecutively. Therefore, the total production of both steel products was 94.62 million tons or 4.17 million tons $(4.2 \%)$ decrease, but managed to maintain the 90 million ton level two years consecutively (Table 1).

As mentioned above, although the 100 million ton level was maintained for crude steel production in terms of volume, the price marked a historical drop. However, production decrease and inventory reduction were done for $\mathrm{H}$ shapes, and the effects of such efforts were seen in the latter half of 2001, so the price continues to improve. For steel plate and strip products, there was action for production cut since there was concern for overstock which became conspicuous as figures from the fourth quarter of 2001. Moreover, inventory reduction progressed slowly due to decreased domestic consumption, so improvement in price is expected to be taken place in 2002.

Export of all iron and steel products was 30.48 million tons or 1.32 million tons (4.5\%) increase compared to 2000 , which was five years consecutive increase. Looking at the details, the situation is completely opposite against that of 2000. Pig iron and half-products increased greatly, while ordinary and special steel products and secondary products decreased. For ordinary steel products, heavy plates and pipes increased, but main product steel and strips (hotrolled wide strips, galvanized sheets, cold-rolled wide strips, tin plates, and electrical strips) decreased significantly. For country of export, Korea and China increased three years consecutively, and the United States increased for the first time in three years, while Taiwan showed two years consecutive decrease, and Thailand decreased for the first time in three years.

Import of all iron and steel products was 6.08 million tons or 1.66 million tons $(21.5 \%)$ decrease compared to 2000. Looking at the details, while secondary products and special steel products increased, hot-rolled wide strips, ferroalloy, cold-rolled wide strips, heavy plates, galvanized sheets, and pig iron decreased. Products that particularly increased among ordinary steel products, which was the main product, included only coated sheets, sheet piles, and shapes, which were small in volume. By country of import, the main countries of Korea, Taiwan, and China decreased to the level below 2000.

The number of employees working in the iron and steel industry as of December 2001 was 178718 workers, which was decrease of about 13000 workers (6.6\%) compared to the end of 2000. The rate of decrease increased past $1 \%$ compared to previous year [decrease of about 11000 workers $(5.3 \%)]$, and this was annual decrease of over $5 \%$ for eight years consecutively since 1994 . The particulars were: $4.9 \%$ decrease in iron and steel, $4.0 \%$ decrease in processing, and $11.1 \%$ decrease in other fields.

In such severe environment, following 2000, the blast furnace industry withdrew from unprofitable products, engaged in cooperation by products, worked on collaboration for each supplementary divisions including distribution, maintenance, and procurement, and participated in technological cooperation with overseas iron and steel companies to deal with the globalization movement. In the electric furnace industry, business cooperation were done actively mainly in the Kansai region. Specific examples included: conclusion of basic agreement between NKK Corp. and Kawasaki Steel Corp. on managerial integration (holding company to be established in October 2002, corporate restructuring by business in April 2003); review of cooperation between Nippon Steel Corp. and Kobe Steel, Ltd., as 
well as between Nippon Steel Corp. and Sumitomo Metal Industries, Ltd. (mutual cooperation in iron resource distribution and resource procurement to promote cost reduction and to enhance iron material supply system); decision by Nakayama Steel Works, Ltd. to withdraw from blast furnace business; and merging of Kansai Steel Corp. and Rinko Steel Work Co., Ltd. (new company name will be Shinkansai Steel Corp.).

Such activities are positioned as structural reform for strengthening the Japanese iron and steel industry to deal with increased competition due to further economic globalization as well as supplier selection policy due to customer choice and concentration, and this is expected to continue for next few years.

Plans to restructure excessive iron and steel industry facilities in worldwide scale were discussed in the high level iron and steel meeting of the Organization for Economic Cooperation and Development (OECD), and the interim report of "Study Group on Future Prospect and Competitiveness of Iron and Steel Industry" was submitted by the Ministry of Economy, Trade and Industry, so reviews pertaining to the issue of excessive facilities are expected to proceed.

\section{Technology and Facility}

\subsection{Ironmaking}

Pig iron production in 2001 was 78.83 million ton, $2.8 \%$ decrease compared to previous year, and it did not reach the 80 million ton mark for first time in two years. Average pig iron productivity was $1.94 \mathrm{t} / \mathrm{m}^{3} \cdot$ day, which was slight decrease compared to $2.00 \mathrm{t} / \mathrm{m}^{3} \cdot$ day of previous year.

For the state of operation of blast furnaces in 2001, Kimitsu No. 3 BF, Nippon Steel Corp. increased the furnace capacity from $4063 \mathrm{~m}^{3}$ to $4822 \mathrm{~m}^{3}$ and was reblown in. At Muroran No. 2 BF, Hokkai Iron \& Coke Corp. threemonths short-term repair of blast furnace was conducted, and the furnace capacity was expanded from $2269 \mathrm{~m}^{3}$ to $2902 \mathrm{~m}^{3}$ and reblown in. At Kawasaki Steel Corp., the furnace capacity of Mizushima No. 1 BF was expanded from $2156 \mathrm{~m}^{3}$ to $2564 \mathrm{~m}^{3}$ and reblown in, and Mizushima No. 4
BF was blown out in October. Mizushima No. 2 BF, Kawasaki Steel Corp., which was blown in on March 20, 1979 , continued to renew the world record of furnace lifespan. The number of blast furnaces in operation as of end of 2001 was 31 , which was same as the beginning of the year (Mizushima No.4 BF was reblown in in January 2002, so currently 32 furnaces are in operation).

For blast furnace operation technology, Kobe No.3 BF, Kobe Steel, Ltd. was successful in completely replacing sintering ore, which was conventionally used as iron ore material, with pellet ore, through the development of burden distribution control and technology for charging of pellet by grade in furnace. All pellet operation (73\% pellet ore, $27 \%$ lumpy ore) started at the end of September, as only such ironwork in Japan.

Figure 1 shows the rate of pulverized coal injection (PCI) into blast furnaces in 2001, and the average PCI ratio for January-June 2001 was $128.5 \mathrm{~kg} / \mathrm{t}$, which was almost same was previous year $(128.6 \mathrm{~kg} / \mathrm{t})$. This was because the pig iron production decreased $2.8 \%$ compared to previous year, so the effect of increasing PCI rate was small, and PCI was reduced for blow-out and blow-in during the four blast furnace relining.

For recycling technology, Kobe Steel, Ltd. installed a dust recycle plant with rotating hearth at Kakogawa Works and commenced operation (see Topics p. 577). At this plant, dezincification process of ironmaking dust, which conventionally could not be reused, and manufacture of high-grade reduced iron were done, to reuse the dust as steelmaking or blast furnace material. This was second such plant in Japan following Hirohata Works, Nippon Steel Corp. In slag use technology, NKK Corp. demonstrated that water-granulated slag from blast furnaces could be used as sand capping material for ocean floor with environmental improvement effects of inhibiting production of red tide and blue tide. So the granulated BF slag which would cover about 4 ha was used in "the Nakaumi water cleanup and sand capping project" supervised by the Izumo Public Work Office of the Ministry of Land, Infrastructure and Transport.

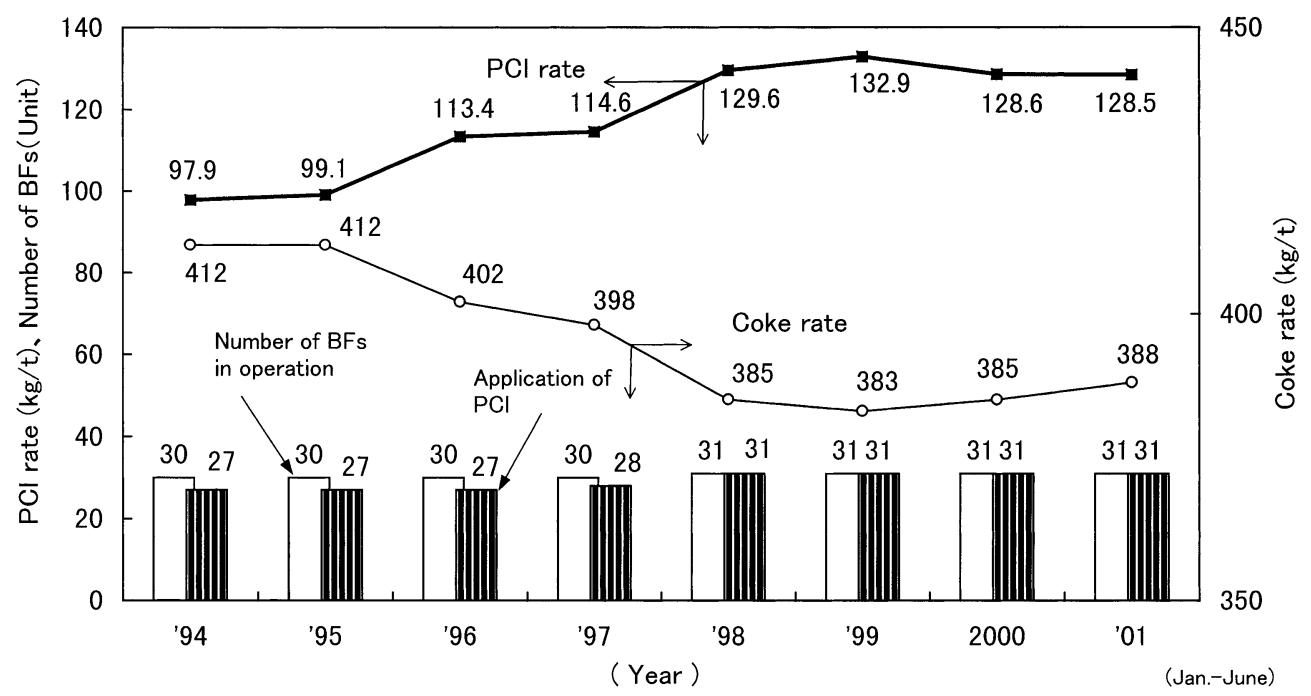

Fig. 1. Incraese in pulverized coal rate injected into blast furnace in Japan. Souce: The Japan Iron and Steel Federation. 
Table 2. Operation performance of converter.

\begin{tabular}{|c|c|c|c|c|c|c|}
\hline & \multirow{2}{*}{$\begin{array}{l}1998 \\
\text { Average }\end{array}$} & \multirow{2}{*}{$\begin{array}{l}1999 \\
\text { Average }\end{array}$} & \multirow{2}{*}{$\begin{array}{l}2000 \\
\text { Average }\end{array}$} & \multicolumn{2}{|l|}{2001} & \multirow{2}{*}{$\begin{array}{l}2001 \\
\text { (Jan.-June) } \\
\text { Average }\end{array}$} \\
\hline & & & & $\begin{array}{l}\text { Jan.- } \\
\text { March }\end{array}$ & $\begin{array}{l}\text { April- } \\
\text { June }\end{array}$ & \\
\hline Productivity index per steelmaking hour* & 102 & 102 & 105 & 105 & 108 & 107 \\
\hline Steelmaking time index per tap to tap* & 98 & 98 & 98 & 97 & 96 & 97 \\
\hline Pig iron mixing ratio(\%) & 95.5 & 93.6 & 92.1 & 91.5 & 92.0 & 91.8 \\
\hline Hot metal mixing ratio(\%) & 94.2 & 92.8 & 91.1 & 90.1 & 91.0 & 90.6 \\
\hline Oxygen consumption $\left(\mathrm{Nm}^{3} / \mathrm{t}\right)$ & 59.2 & 60.4 & 59.5 & 60.1 & 59.1 & 59.6 \\
\hline Ratio of continuous cast steel( $\%)$ & 99.2 & 99.3 & 99.3 & 99.2 & 99.3 & 99.3 \\
\hline Ratio of vacuum treated steel(\%) & 61.6 & 62.4 & 63.3 & 64.9 & 65.4 & 65.2 \\
\hline
\end{tabular}

* The index is based on the average of $1995 \sim 1997,100$

Source: The Iron and Steel Federation

Table 3. Operation performance of electric furnace.

\begin{tabular}{|c|c|c|c|c|}
\hline & $\begin{array}{c}1998 \\
\text { Average }\end{array}$ & $\begin{array}{c}1999 \\
\text { Average }\end{array}$ & $\begin{array}{c}2000 \\
\text { Average }\end{array}$ & $\begin{array}{c}2001 \\
\text { Jan.-June }\end{array}$ \\
\hline Productivity index per steelmaking hour* & 106 & 97 & 98 & 98 \\
\hline Electric power consumption per ton of good ingot ( $\mathrm{kWht})$ & 402.5 & 406.8 & 414.2 & 414.2 \\
\hline Oxygen consumption per ton of good ingot $\left(\mathrm{Nm}^{3} / \mathrm{t}\right)$ & 22.5 & 20.8 & 20.0 & 20.0 \\
\hline Yield of good ingots $(\%)$ & 91.5 & 91.4 & 91.4 & 91.4 \\
\hline Ratio of good continuously cast steel (\%) & 89.4 & 88.2 & 87.7 & 87.7 \\
\hline Ratio of alloy steel (\%) & 32.3 & 35.9 & 37.7 & 38.2 \\
\hline
\end{tabular}

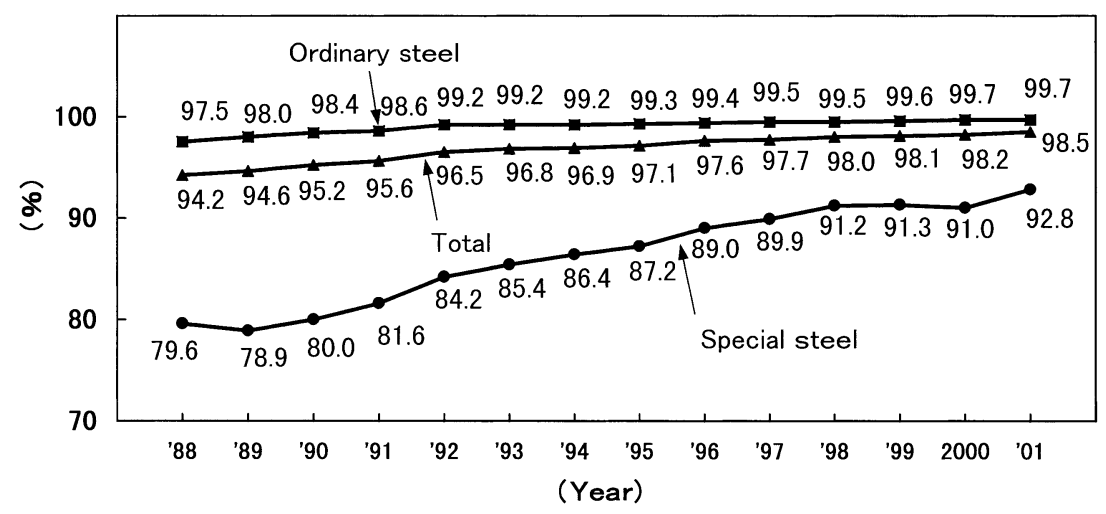

Fig. 2. Change of ratio of continuous casting production. Source: The Japan Iron and Steel Federation.

\subsection{Steelmaking}

For steelmaking, as shown in the work performance of converter in Table 2 and work performance of electric furnace in Table 3, the productivity index per steelmaking hour slightly improved for converters, but decrease trend continued for electric furnaces.

The ratio of continuously cast steel billet among hotrolled steel ingot is shown in Fig. 2. Ordinary steel remained the same compared to $99.7 \%$ of previous year, while special steel increased to $92.8 \%$ from $91.0 \%$ of previous year.

Improvements in steelmaking process included the following: development of CAS-OB with reduced pressure refining function at Nagoya Works, Nippon Steel Corp. (see Topics p. 577); concentration and rationalization of manufacture process of highly clean steel with additional slag refining function by converting the existing $\mathrm{RH}$ facility to Ladle Furnace at Muroran Works, Nippon Steel Corp.; improvement of vacuum processing capacity by new construction of \#5RH at Fukuyama Works, NKK Corp.; and estab- lishment of low cost melting technology through pooling and concentrated melting during night using electric furnace at Chita Plant, Daido Steel Co., Ltd.

Other activities included the following: cost rationalization by installation of one of the largest air separators in Japan (air processing volume $243000 \mathrm{~m}^{3} / \mathrm{hr}$ ) at Fukuyama Works, NKK Corp.; and expansion of dephosphorization capacity and construction of integrated manufacture system by product type through renovation of continuous caster at Kashima Steel Works, Sumitomo Metal Industries, Ltd.

\subsection{Plates; Pipes and Tubes; Sections, Wires, and Rods}

For plates, Nippon Steel Corp. developed the HTUFF technology, which improved toughness and powerfully inhibited the bulking of structure of HAZ (heat affected zone) by copiously dispersing fine particles of oxides and sulfides in steel. This technology was applied to heavy steel plates for ocean structures and steel construction.

Kobe Steel, Ltd. developed an online material quality 
control technology which optimized the material as well as formed productivity through pass schedule setting model which incorporated material projection model. It also developed a technology to feed forward the draft position correction to next pass by estimating temperature from rolling load (temperature estimation type FF-AGC) without using a thickness gage, and applied this technology to steel plates rolling.

For wires and rods, Sumitomo Metals (Kokura), Ltd. installed a roller hearth type continuous annealing facility for wire rod, which was equipped with rapid preheating chamber and rapid cooling chamber, and worked on large-scale energy saving and quality improvement at heat treatment.

Chita Plant, Daido Steel Co., Ltd. added three mills in the finishing row of the wire rod rolling facility. This greatly improved the controlled rolling capacity, as well as achieved partial curtailing of secondary processing (annealing and wire drawing).

Technical Research Laboratories, Kawasaki Steel Corp. developed an analysis technology for measuring the maximum particle diameter and distribution of particle diameter by form of inclusions in bearing steel using spark emission analysis, and enabled quick measurement in $30 \mathrm{~min}$ (conventionally, this procedure required several days).

For sections, Mizushima Works, Kawasaki Steel Corp. developed a technology for measuring the center gap of $\mathrm{H}-$ shapes using two laser distance meter, and enabled measurements during runs.

Head Office Works, Shinkansai Steel Corp. installed continuous steel billet heating furnace with six regenerative burners and fiber lining furnace walls (walking beam conveyor).

Rinko Works, Shinkansai Steel Corp. installed a descaling device of $16 \mathrm{MPa}$ spec. which can peel anchored scales, and improved surface finish and form. Also, it installed rest bar equipment (automated transfer) that could control vertical direction position by horizontal positioning of the attachment of rolling $\mathrm{V}$ stand guide.

\subsection{Sheets}

\subsubsection{Hot-rolling Process}

Chiba Works, Kawasaki Steel Corp. developed and installed for the first time in the world, an ultrasonic flaw detector (defect reflection wave detection) which allowed inline detection of minute inclusions (about $50 \mu \mathrm{m}$ ) for entire surface and for cross section of sheets. Also, it installed surface flaw detector (detection of regular and irregular reflection with CCD camera) which detected and identified only harmful surface flaws online.

Kashima Steel Works, Sumitomo Metal Industries, Ltd. developed control system applied to the acid pickling reaction model, as well as device that enabled continuous acid concentration measurement in the acid pickling line and put them to practical use.

Fukuyama Works, NKK Corp. employed regenerative burner in the No. 2 heating furnace of the first hot-rolling line, and achieved significant energy saving and ultra low $\mathrm{NO}_{x}$. It also introduced crude bar heating device, so that even temperature control over the entire length of slab became possible.

\subsubsection{Cold-rolling and Surface Treatment Processes}

NKK Steel Sheet \& Strip Corp. employed LINUX for the first time in the world for its process control computer for the continuous galvanizing line. This was an attempt to significantly decrease the system building expenses.

Fukuyama Works, NKK Corp. introduced the defect marking facility (Delta Eye) to 3CGL and 4CAL, following $2 \mathrm{CGL}$, and worked on increasing weight of coil for automobiles through quality improvement.

\subsubsection{Hoop Steel}

Hoshizaki Plant, Daido Steel Co., Ltd. introduced a steckel mill for rolling hoop steel of high alloy containing nickel. It had capacity for maximum width $750 \mathrm{~mm}$ and coil weight 7 ton.

\subsection{Miscellaneous}

For equipment related activities, Kansai Steel Division, Sumitomo Metal Industries, Ltd. commenced operation of 5000 ton high-speed forging press line, which was compact yet had world highest productivity. This was done in pursuit of process optimization to respond to the trend for using forged steel in automobile crank shaft. Also, Sumitomo Metals (Naoetsu), Ltd. installed a pressure permeation acid recovered equipment, which realized high concentration of recovered acid as well as reduction of waste acid, while resolving the shortcoming of diffusion dialysis.

For analysis related activities, Technical Research Laboratories, Kawasaki Steel Corp. succeeded in the development of high precision analysis method for trace oxygen in steel, which was not affected by surface pollution, through complete removal of surface pollution of samples with ion spattering.

\section{Technology Export and Import}

For the particulars of technological trade in the year 2001, the results of survey conducted among the supporting member companies of ISIJ are shown in Table 4. The number of technology exports was 37 cases compared to 138 cases in previous year, technology import was five cases compared to 14 cases in previous year, and there was a marked decline. Exports were done to Asia which dominated $41 \%$, followed by Europe and Middle/South America. There was only one case of export to North America, where there were 30 cases $(22 \%)$ in 2000 . By technological field, $41 \%$ were process and treatment, $24 \%$ were ironmaking, $22 \%$ were steelmaking, and these three dominated $86 \%$ of the total. There was only one case of overall operation, which dominated $18 \%$ in 2000 , and this was a significant decrease. Figure 3 shows the balance of technology trade of the iron and steel industry. In $2000 \mathrm{FY}$, the technology import against payment receipt was about the same as $1999 \mathrm{FY}$, but the technology export against payment receipt increased, and the amount of export-import balance rose from 9.1 billion to 11.1 billion yen. The surplus trend is expected to remain in $2001 \mathrm{FY}$.

\section{Research Expenditure}

Figures 4 through 8 show the corporate research expenditures and changes in number of researchers according to 
Table 4. Contents of technology export and technology import. (Term: January 1, 2001-December 31, 2001)

\begin{tabular}{|c|c|c|c|c|c|c|c|c|}
\hline & Field & Asia & $\begin{array}{l}\text { North } \\
\text { America }\end{array}$ & $\begin{array}{l}\text { Central } \\
\text { \& South } \\
\text { America }\end{array}$ & Europe & Oceanic & Africa & Total \\
\hline \multirow[t]{6}{*}{$\begin{array}{l}\text { Technical } \\
\text { export }\end{array}$} & $\begin{array}{l}\text { (A) Raw Materials, } \\
\text { Ironmaking } \\
\text { 1)Coke plant operation } \\
\text { 2)Raw materials handling } \\
\text { facilities } \\
\text { 3)Blast furnace operation } \\
\end{array}$ & 3 & & 1 & 2 & 1 & & $\begin{array}{l}2 \\
2 \\
5\end{array}$ \\
\hline & $\begin{array}{l}\text { (B) Steelmaking } \\
\text { 1)Hot metal pretreatment } \\
\text { 2)Converter } \\
\text { 3)Electric furnace } \\
\text { 4)Secondary refining } \\
\text { 5)Continuous casting, } \\
\text { ingotmaking } \\
\text { 6)Auxiliary facilities }\end{array}$ & 1 & & $\begin{array}{l}1 \\
1 \\
1\end{array}$ & 2 & 1 & & $\begin{array}{l}1 \\
3 \\
1 \\
1 \\
1 \\
1\end{array}$ \\
\hline & $\begin{array}{l}\text { (C) Shaping, Processing } \\
\text { 1)Bar and wire rod } \\
\text { 2)Pipe and tube } \\
\text { 3)Sheet } \\
\text { 4)Surface treatment } \\
\text { 5)Heat treatment } \\
\end{array}$ & $\begin{array}{l}1 \\
1 \\
5 \\
1\end{array}$ & & $\begin{array}{l}2 \\
1\end{array}$ & $\begin{array}{l}1 \\
1\end{array}$ & 1 & 1 & $\begin{array}{l}4 \\
1 \\
8 \\
1 \\
1\end{array}$ \\
\hline & \begin{tabular}{|l|} 
(D) Other Operation Know-how \\
(incl. Research related)
\end{tabular} & & 1 & & & & & 1 \\
\hline & \begin{tabular}{|l} 
(E) Iron and Steel Works in \\
General \\
1)Others
\end{tabular} & 2 & & 1 & 1 & & & 4 \\
\hline & \begin{tabular}{|r|} 
Total \\
\end{tabular} & 15 & 1 & 8 & 9 & 3 & 1 & 37 \\
\hline \multirow[t]{2}{*}{$\begin{array}{l}\text { Technical } \\
\text { import }\end{array}$} & \begin{tabular}{|l} 
(C) Shaping, Processing \\
1) Pipe \& tubes \\
2) Surface treatment \\
3) Forming \\
\end{tabular} & & $\begin{array}{l}2 \\
1\end{array}$ & & $\begin{array}{l}1 \\
1 \\
\end{array}$ & & & $\begin{array}{l}3 \\
1 \\
1\end{array}$ \\
\hline & Total & 0 & 3 & 0 & 2 & $\mathbf{0}$ & $\mathbf{0}$ & 5 \\
\hline
\end{tabular}

(Coverage: 43 sustaining member companies of ISIJ)

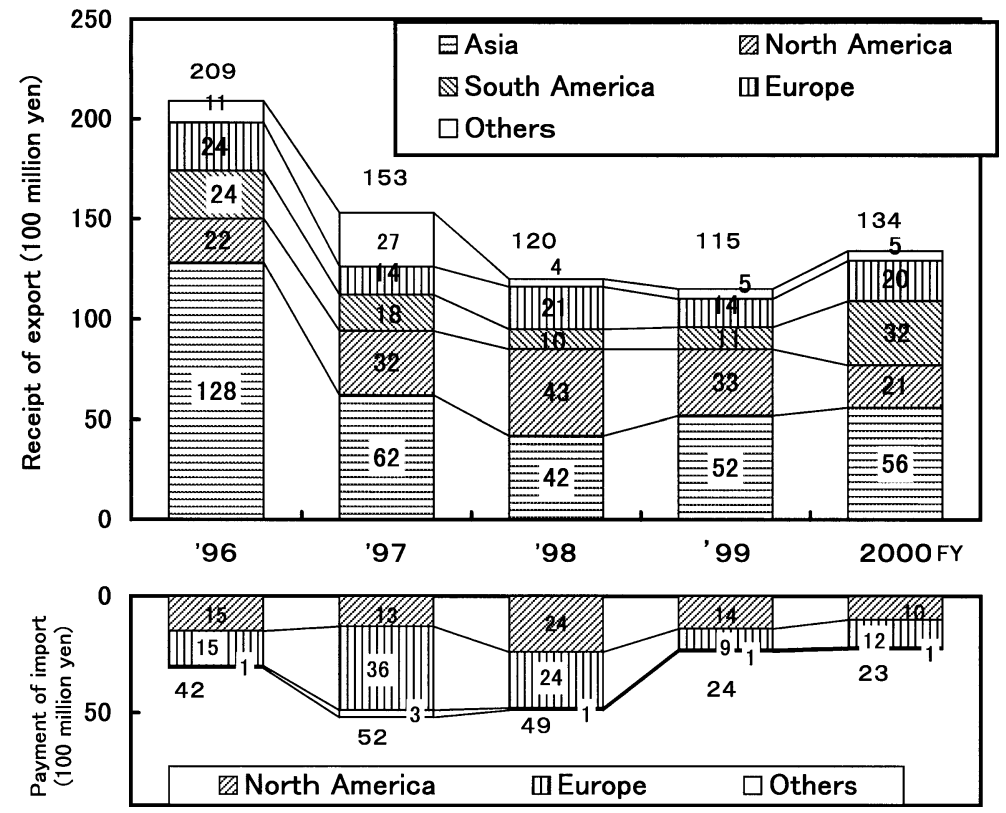

Fig. 3. Balance of technology trade of steel.

Source: "Report on the Survey of the Research and Development", Statistics Bureau \& Statistic Center.

"Report on the Survey on Research and Development" of the Statistics Bureau \& Static Center, the Ministry of Public Management, Home Affairs, Posts and Telecommunications.

For the whole industry, the total company-use research expenditure hit the ceiling, and the decrease trend continued in the iron and steel industry ever since $1992 \mathrm{FY}$.

The number of dedicated researchers, which enjoyed long-term continued increase for the whole industry, also seemed to hit the ceiling, and the decrease trend continued in the iron and steel industry except for $1998 \mathrm{FY}$.

Although the ratio of research expenditure against sales was on slight decrease trend for the whole industry, it stayed at around $3 \%$, and for the iron and steel industry, it was on decrease trend although it showed temporary increase in $1997 \mathrm{FY}$ and $1998 \mathrm{FY}$. 


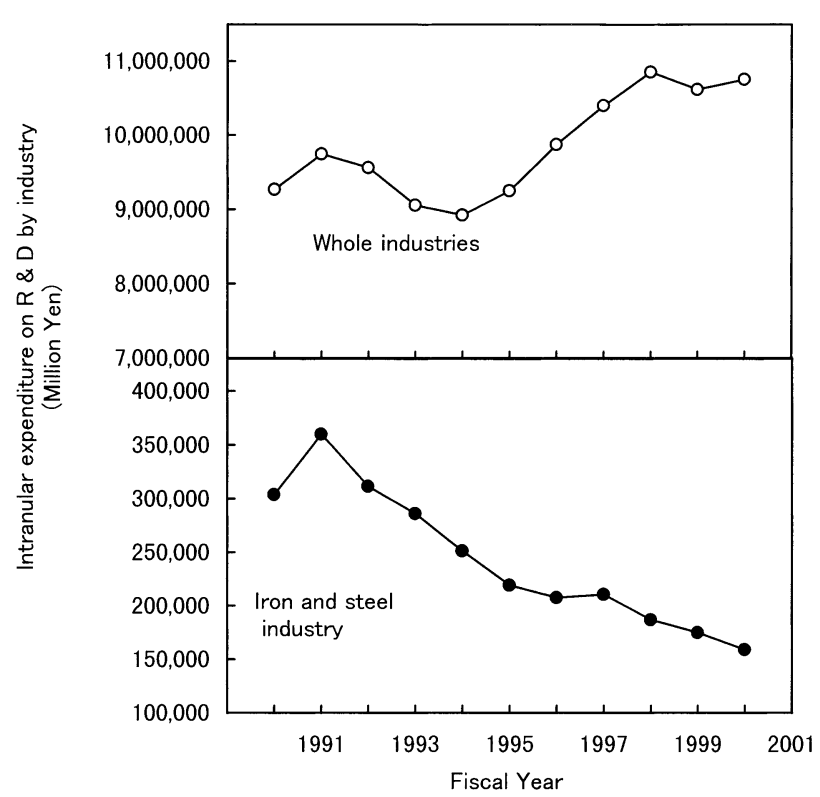

Fig. 4. Trend of the intranural expenditure on $R \& D$ by industry. Source: "Report on the 2001 Survey of the Research and Development", Statistic Bereau \& Statistic Center.

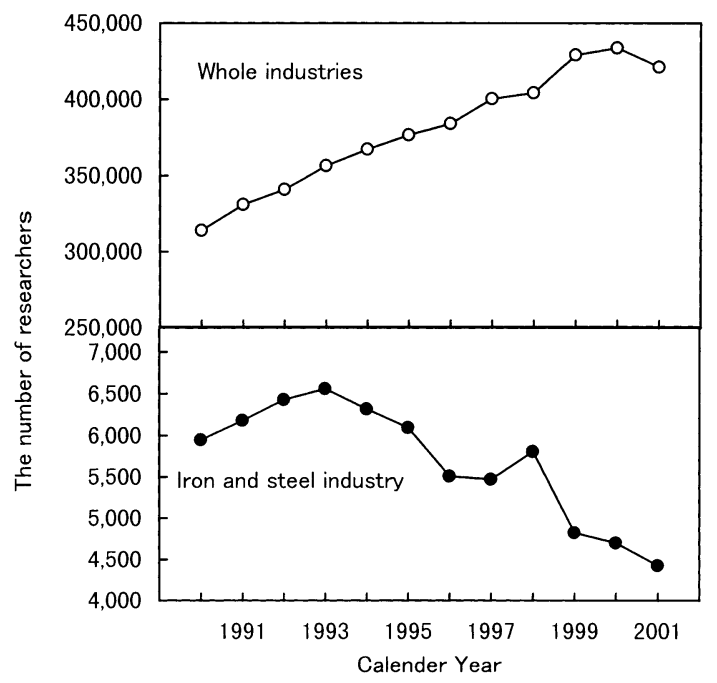

Fig. 5. Trend of the number of regular researcher.

Source: "Report on the 2001 Survey of the Research and Development", Statistic Bereau \& Statistic Center.

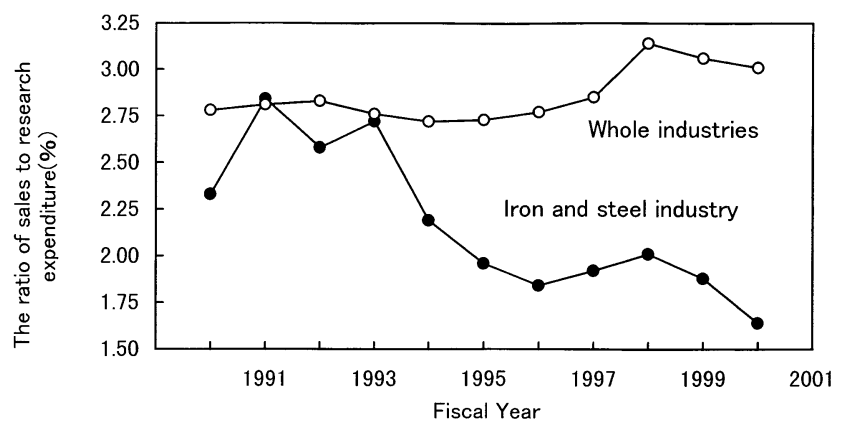

Fig. 6. Trend of the ratio of sales to research expenditure. Source: "Report on the 2001 Survey of the Research and Development", Statistic Bereau \& Statistic Center.

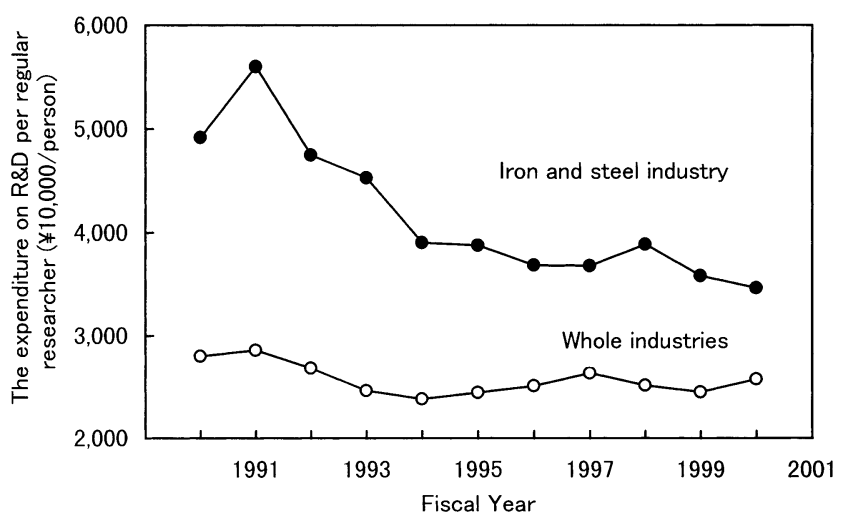

Fig. 7. Trend of the expenditure on R\&D per regular researcher. Source: "Report on the 2001 Survey of the Research and Development", Statistic Bereau \& Statistic Center.

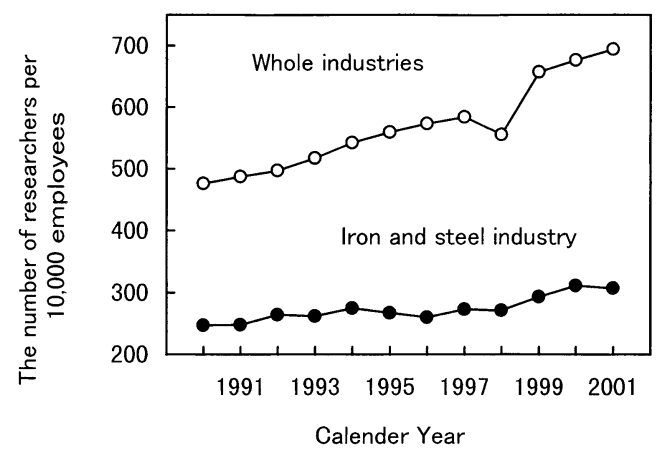

Fig. 8. Trend of the number of researchers per 10000 employees.

Source: "Report on the 2001 Survey of the Research and Development", Statistic Bereau \& Statistic Center.

Table 5. Technology creation activities of Technical Committee, Research Group, and Interdisciplinary Technical Committee.

\begin{tabular}{|l|l|}
\hline $\begin{array}{c}\text { Technology creation } \\
\text { activities }\end{array}$ & \multicolumn{1}{c|}{ Content of activities } \\
\hline Technical Committee & $\begin{array}{l}\text { To promote the exchange of technology information concerning iron and steel production with the aim of improving } \\
\text { the level of the conventional technologies, to extract technological tasks in each category and implement researches. } \\
\text { Twenty Committees cover all iron and steel production are established, and engineers and researchers from industry } \\
\text { and university researchers as well, are participating in each Committee. Meeting is held once or twice a year. } \\
\text { "Technical Subcommittees" that discuss technological problems are established as subordinate organization, and their } \\
\text { activities provide basis for technology creation. }\end{array}$ \\
\hline Research Group & $\begin{array}{l}\text { To conduct the joint research on specific and important subjects for iron and steel industry based on the needs from } \\
\text { industry and seeds from academia. }\end{array}$ \\
\hline $\begin{array}{l}\text { Interdisciplinary } \\
\text { Technical Committee }\end{array}$ & $\begin{array}{l}\text { To make technical examinations and surveys on future development and solution about interdisciplinary } \\
\text { technological problems within the iron and steel industry and with other industries. }\end{array}$ \\
\hline
\end{tabular}


Table 6. Activities of the Technical Committees.

\begin{tabular}{|c|c|}
\hline Committees on & $\begin{array}{l}\text { Common subject } \cdot \text { Particular subject } \cdot \text { Report from Technical } \\
\text { Subcommittee } \\
\text { (1):Meeting in spring, (2)Meeting in autumn) }\end{array}$ \\
\hline Ironmaking & $\begin{array}{l}\text { (1) Lengthening the life span of blast furnaces and future corresponding } \\
\text { technology; Technical Subcommittee report }\end{array}$ \\
\hline Coke & $\begin{array}{l}\text { (1) 6th Reporting of Production Technology } \\
\text { (2) On stable operation of coke oven; Research Group report }\end{array}$ \\
\hline Steelmaking & $\begin{array}{l}\text { (1) Secondary refining } \\
\text { (2) Attainment of high efficiency in continuous casting process; Special } \\
\text { lecture "Latest technology in slab CC revamping" }\end{array}$ \\
\hline Electric Furnace & $\begin{array}{l}\text { (1) Recycling of industrial waste } \\
\text { (2) Total energy of electric furnace; Special lecture "A discussion on total } \\
\text { energy of electric furnace process" }\end{array}$ \\
\hline Special Steel & $\begin{array}{l}\text { (1) Quality improvement in secondary dissolving } \\
\text { (2) Improvement of ingot casting technology }\end{array}$ \\
\hline Refractories & $\begin{array}{l}\text { (1) Panel discussion "The outcome of imported refractories," "End-point } \\
\text { determination technology"; Special lecture "Circumstances of } \\
\text { overseas refractories and measures taken by Japanese refractories } \\
\text { manufacturers" } \\
\text { (2) Joint meeting with The Technical Association of Refractories, Japan; } \\
\text { Research report }\end{array}$ \\
\hline Heavy Plate & $\begin{array}{l}\text { (1) Plant operation status report } \\
\text { (2) Response to customer demand; Plant operation status report }\end{array}$ \\
\hline Hot Strip & $\begin{array}{l}\text { (1) Special lecture "Basic research on changes in form of surface flaw } \\
\text { during hot-rolling"; Foremen's study session } \\
\text { (2) Foremen's study session "Safety and disaster prevention" }\end{array}$ \\
\hline Cold Strip & $\begin{array}{l}\text { (1) Plant operation status report; Foremen Group "Human resource } \\
\text { education and craftsmanship tradition" } \\
\text { (2) Rolling oil }\end{array}$ \\
\hline Coated Steel Sheet & $\begin{array}{l}\text { (1) Environment, safety, and disaster prevention } \\
\text { (2) Technical Subcommittee report; Plant operation status report }\end{array}$ \\
\hline Large Section & $\begin{array}{l}\text { (1) Joint meeting with Section Forum } \\
\text { (2) Special lecture "Introduction of new shape steel plant of Osaka Steel } \\
\text { Co. Ltd."; Technical Subcommittee report; Industry-university } \\
\text { exchange activity report }\end{array}$ \\
\hline $\begin{array}{l}\text { Medium and Small } \\
\text { Sections }\end{array}$ & $\begin{array}{l}\text { (1) Plant operation status report; Theme research; Foremen Group } \\
\text { discussion; Special lecture "Recent trend in bar steel rolling plant" } \\
\text { "Rolling of high precision bars with Reducing and Sizing Block (RSB) } \\
\text { to improve both product quality and mill economy" } \\
\text { (2) Plant operation status report }\end{array}$ \\
\hline Wires and Rods & $\begin{array}{l}\text { (1) Plant operation status report } \\
\text { (2) Plant operation status report; Special lecture "Progress in rolling } \\
\text { technology and future perspective","Progress in wire rod rolling plant } \\
\text { and future perspective" }\end{array}$ \\
\hline $\begin{array}{l}\text { Steel Pipes and } \\
\text { Tubes }\end{array}$ & $\begin{array}{l}\text { (1) Plant operation status report; Special lecture "Latest trend in supply } \\
\text { chain management - next generation CSM:B2B /SCM" } \\
\text { (2) Technical Subcommittee report; Plant operation status report }\end{array}$ \\
\hline Rolling Theory & $\begin{array}{l}\text { (1) Development of sheet/plate/wire rod rolling, steel pipe rolling/forming, } \\
\text { and related technologies; Special lecture " } 40 \text { years of history with the } \\
\text { Technical Committee on Rolling Theory" } \\
\text { (2) Development of sheet/plate/wire rod rolling, steel pipe rolling/forming, } \\
\text { and related technologies; Special lecture "Development of rolling and } \\
\text { material" }\end{array}$ \\
\hline $\begin{array}{l}\text { Heat Economy } \\
\text { Technology }\end{array}$ & (2) Technical Subcommittee report \\
\hline Control Technology & $\begin{array}{l}\text { (1) Special session "Recent trend in control theory", "Trend in power } \\
\text { reception/distribution technology" } \\
\text { (2) Special lecture "Application of network security technology to } \\
\text { industrial fields" }\end{array}$ \\
\hline Plant Engineering & $\begin{array}{l}\text { (1) Technical Subcommittee report "Stable operation of converter exhaust } \\
\text { gas processing plant and technology for reducing maintenance cost" } \\
\text { (2) Anticorrosive/anti-abrasive materials in ironmaking plant and } \\
\text { technology for material surface modification }\end{array}$ \\
\hline Quality Control & $\begin{array}{l}\text { (1) (QAQC Division) Issue of quality assurance at times of personnel } \\
\text { reduction and future measures } \\
\text { (2) (NDI Division) Technical Subcommittee report; NDI regular status } \\
\text { survey "Wire rod and shape"; Special lecture "Visualization of } \\
\text { ultrasonic by animated image and computer simulation" }\end{array}$ \\
\hline Analysis Technology & $\begin{array}{l}\text { (1) Technical Subcommittee report } \\
\text { (2) Technical Subcommittee report; Special lecture "New analysis method } \\
\text { using X-ray - after Bulletin of The Iron and Steel Institute of Japan" }\end{array}$ \\
\hline
\end{tabular}


Table 7. Objectives of new Research Groups and results of Research Group that completed activities in $2001 \mathrm{FY}$.

\begin{tabular}{|c|c|c|c|}
\hline & Research Group & Objectives/Results of Activity & $\begin{array}{l}\text { Activity term } \\
\text { (Fiscal Year) }\end{array}$ \\
\hline \multirow[t]{4}{*}{ New Group } & $\begin{array}{l}\text { Porous Meso-mosaic Tex- } \\
\text { ture Sinter }\end{array}$ & $\begin{array}{l}\text { (1) In two years, the ratio of Marra Mamba goethitic iron ore unsuitable for sintering } \\
\text { will increase rapidly, and the amount of sinter necessary for the Japanese iron and steel } \\
\text { industry cannot be produced satisfactorily. Therefore, the method of using goethitic } \\
\text { iron ore, high combined water content and high porosity, has been studied and the } \\
\text { combination with low slag ratio important for melting goethitic iron ore will be studied. } \\
\text { (2) Each university has been engaged in basic research such as granulation, } \\
\text { agglomeration, evaluation of reaction in blast furnace and others to propose a new } \\
\text { process for "porous meso-mosaic texture sinter" which simultaneously realizes high } \\
\text { strength and high reducibility under the conditions of low slag and high goethitic iron } \\
\text { ore ratio in sintering. (3) By combining these basic researches, the theory of } \\
\text { agglomeration and the engineering foundation for raw material / sintering / blast } \\
\text { furnace process can be constructed and a new process of "porous meso-mosaic texture } \\
\text { sinter" based on improving granulation process of raw material can be proposed. }\end{array}$ & $2001-2004$ \\
\hline & $\begin{array}{l}\text { Clarification of Rust Pre- } \\
\text { vention Mechanism of } \\
\text { Coated Steel Plates and } \\
\text { Lifespan Design }\end{array}$ & $\begin{array}{l}\text { The following points will be clarified in order to establish method for } \\
\text { lifespan design of coated steel plates: (1) To clarify the condition and } \\
\text { mechanism of corrosion product, and to study its property, function, } \\
\text { and structure, (2) to clarify the rust prevention mechanism of corrosion } \\
\text { product, and (3) to quantify the corrosive environment and to clarify the } \\
\text { relationship to rust prevention mechanism. }\end{array}$ & $2001-2004$ \\
\hline & $\begin{array}{l}\text { Influence of Scale Proper- } \\
\text { ties on Surface Characte- } \\
\text { ristics of Steels }\end{array}$ & $\begin{array}{l}\text { (1) To measure the basic property values of scales such as hardness, breaking } \\
\text { strain, and Young's modulus, and to evaluate the plastic deformation capacity of } \\
\text { scales. (2) To investigate the effects of additional trace elements or oxidation } \\
\text { condition on property of scale-steel interface and adhesion of scales, and to clarify } \\
\text { the relationship to descaling property. (3) To clarify the effect of trace elements and } \\
\text { oxidation condition on hot brittleness. (4) To conduct the above investigations for } \\
\text { secondary scales. (5) To review the above results and to establish method for } \\
\text { avoiding steel surface defects. }\end{array}$ & $2001-2004$ \\
\hline & $\begin{array}{l}\text { Development of Analytical } \\
\text { Methods for Trace Impu- } \\
\text { rity Elements in Iron and } \\
\text { Steel with Expanded Use } \\
\text { of Scrap }\end{array}$ & $\begin{array}{l}\text { In order to recycle the increasing scrap and yet maintain the quality of } \\
\text { iron and steel as well as Japan's world-class competitiveness in steel } \\
\text { products such as automobiles and industrial machinery, technologies to } \\
\text { remove impurities of elements and to evaluate them are necessary, and } \\
\text { their development is urgent. Particularly, when scrap use is expanded to } \\
\text { steel sheets and surface-treated high-grade steel, removal of tramp } \\
\text { elements in steel and quality control of their concentration become } \\
\text { mandatory. At present the technologies to determination of tramp } \\
\text { elements with concentration of less than } 10 \mathrm{ppm} \text { are required. However, } \\
\text { the determination level of tramp elements under the current JIS law is } \\
\text { about } 20 \mathrm{ppm} \text {, which does not meet goal of quality control for precision. } \\
\text { Therefore, in this study, university researchers who are developing top } \\
\text { level of trace analytical methods and corporate technicians who are } \\
\text { routinely developing trace analytical methods for iron and steel will } \\
\text { collaborate to develop a new analytical technology. In the development of } \\
\text { analytical technology, the development of chemical analysis, which will be } \\
\text { used as a definitive method, will be done to establish precision for } \\
\text { analysis. Emission spectrochemical analysis based on the developed } \\
\text { chemical analysis is also developed to establish rapid analytical } \\
\text { technology. }\end{array}$ & $2001-2004$ \\
\hline \multirow[t]{3}{*}{$\begin{array}{l}\text { Group } \\
\text { Completed }\end{array}$} & $\begin{array}{l}\text { Thermoplasticity } \\
\text { Mechanism of Coal } \\
\text { Particles }\end{array}$ & $\begin{array}{l}\text { Agglomeration structure relaxation by breaking of hydrogen bond in } \\
\text { coal polymers, softening flow and expansion by dissociation of monomeric } \\
\text { substances, and formation and resolidification of carbon network } \\
\text { structure were clarified. These enabled the theoretical estimate of caking, } \\
\text { and the engineering foundation for coal use was established. }\end{array}$ & $1998 \sim 2001$ \\
\hline & $\begin{array}{l}\text { Rapid and High-sensiti- } \\
\text { vity Analysis for Steel } \\
\text { Production Control }\end{array}$ & $\begin{array}{l}\text { Analysis methods which respond to the demand for speed-up of each } \\
\text { steelmaking process were summarized, prospect of refining limit and } \\
\text { possibility for high-sensitivity analysis were investigated, direction for } \\
\text { future steelmaking process control analysis was sought, and next- } \\
\text { generation analysis method was developed. }\end{array}$ & $1998 \sim 2001$ \\
\hline & $\begin{array}{l}\text { Modeling and Optimiza- } \\
\text { tion of Planning Problems } \\
\text { in Steel Industry-Large } \\
\text { Scale Complex Systems } \\
\text { Approach }\end{array}$ & $\begin{array}{l}\text { To investigate the multi-purpose optimization of production, operation, } \\
\text { and distribution planning for large-scale system of the iron and steel } \\
\text { industry, the subjects were modeled as accurately as possible and study } \\
\text { and evaluation of each theory were conducted. }\end{array}$ & $1998 \sim 2001$ \\
\hline
\end{tabular}

The research expenditure per dedicated researcher was higher for iron and steel industry compared to whole industry, but whole industry showed increase while iron and steel industry showed decrease, and the difference between the two is diminishing.

The number of dedicated researchers per 10000 workers tended to increase for the whole industry, but the number for iron and steel industry hit the ceiling.

\section{Creation of New Technology at the ISIJ}

At the ISIJ, research activities for iron and steel produc- 
Table 8. Research Groups in operation.

\begin{tabular}{|l|c|}
\hline \multicolumn{1}{|c|}{ Research Group on } & $\begin{array}{c}\text { Activity term } \\
\text { (Fiscal Year) }\end{array}$ \\
\hline Advanced Application of Electromagnetic Processing of Materials & $1999 \sim 2002$ \\
\hline $\begin{array}{l}\text { Fixation of Waste } \mathrm{CO}_{2} \text { with Algal Production Enhanced by Enrichment of Steelmaking } \\
\text { Slag }\end{array}$ & $1999 \sim 2002$ \\
\hline $\begin{array}{l}\text { Advanced Diagonosis and Control Techniques for Labor-Saving Based on a Large } \\
\text { Quantity of Data }\end{array}$ & $1999 \sim 2002$ \\
\hline Elucidation of Behavior of Boron and Promotion of Its Usage in Steel & $1999 \sim 2002$ \\
\hline Precipitation Control in Steels & $1999 \sim 2002$ \\
\hline Creation of Innovative High Efficiency Mixing/Separating Reactor & $2000 \sim 2003$ \\
\hline Slag Use for Prefabricated Building Material & $2000 \sim 2003$ \\
\hline Structure and Property of Alloy-Forming Melted Plating Membrane & $2000 \sim 2003$ \\
\hline $\begin{array}{l}\text { Development of Skill-free System for Iron and Steel Process Chemical Analysis } \\
\text { Technology }\end{array}$ & $2000 \sim 2003$ \\
\hline Development of Projection Technology for Surface Defect Occurrence Process & $2000 \sim 2003$ \\
\hline
\end{tabular}

tion technology were conducted by the Technical Society, and categories and contents of the activities are listed in Table 5.

(Academic research for iron and steel are conducted in the Technical Division of the Academic Society, as well as in Forums which are subordinate organizations of the Academic Society.)

\subsection{Technical Committees}

In the Technical Committees, the committees were grouped according to their activities, so they would correspond to the Technical Divisions of the Academic Society, for the purpose of vitalizing exchange between industries and universities, as well as promoting suggestions in technological development issues.

As shown in Table 6, the Committee Meetings in $2001 \mathrm{FY}$ concentrated on common and important subjects that were considered significant at that point, and active discussion were engaged.

Participation of university researchers to the Committee Meetings, which were started to strengthen links between industry and university for technology creation, as well as joint organization and two-way participation with the Technical Divisions of the Academic Society have become standard activities.

For the Committees which convened twice a year, one of the meetings were arranged as one-day meeting dedicated to research discussion, awarding system was introduced to promote activities of the Committee and to improve the quality of papers, and each Committee, while attempting to lighten their load in accordance with their activities, worked to change their mode of operation to create fruitful Committee.

The following 10 Technical Subcommittees were created in $2001 \mathrm{FY}$, and together with Groups that completed activities in the fiscal year, 29 Technical Subcommittee were active.

- Control of critical phenomena in blast furnace for minimizing to $\mathrm{CO}_{2}$ emission (Ironmaking)
- Coking control of plasticized coal (Coke)

- Development and utilization of on-line sensing (in steelmaking process) (Steelmaking)

- QC and QA on surface defects in hot rolling process (Hot Strip)

- Labor saving and productivity (Cold Strip)

- The improvement of the pot equipment life (Coated Steel Sheet )

- Rennovation of 3D FEM analysis system for bar and wire rod rolling (Rolling Theory)

- Maintenance cost reduction and life extension of rolls in cold mill and surface treatment process (Plant Engineering)

- Evaluating the characteristics of new type probes of eddy current testing for ferromagnetic materials (Quality Control)

- Technical analysis with ET-AAS (Analysis Technology)

\subsection{Research Group}

In $2001 \mathrm{FY}$, four Research Groups were created and three completed their activities. The objectives and results of each Group are shown in Table 7. Table 8 shows the activities of continuing Research Groups (excluding those which started or finished in 2001).

\subsection{Interdisciplinary Technical Committee}

"Interdisciplinary Technical Committee on Desirable Steel Materials for Automobile" started its activities for the third period (to 2003 FY). "Interdisciplinary Technical Committee on Phase-Control Metallurgy and Properties of Modern Structural Steel" continued to be active (to be completed in $2002 \mathrm{FY}$ ).

\section{Acknowledgements}

The Author would like to acknowledge: the Ironmaking Planning Office, Iron and Steel Division, Manufacturing Industry Bureau, the Ministry of Economy, Trade and Industry (economic circumstance of the Japanese iron and steel industry); The Japan Iron Steel Federation (various statistical data); and members and staff of the ISIJ. 


\section{论许 Topics 论证}

Technologics, facilities, and products of the supporting member companies of ISIJ to pay attention from January to December 2000 are as follows.

\section{Ironmaking}

\section{Steel Mill Waste Recycling at Kakogawa Works by FASTMET ${ }^{\circledR}$ Process}

\section{Kobe Steel, Ltd}

The second commercial plant of FASTMET ${ }^{\circledR}$ process started operation since April 2001 at Kakogawa Works, Kobe Steel, Ltd. for recycling the steel mill waste by utilizing the Kakogawa Demonstration Plant with modifications for the commercial operation.

One of the features of FASTMET ${ }^{\circledR}$ Process adopts one or two layers of loaded pellets/briquettes in the rotary hearth furnace for reactions, which allows not only high furnace temperature without making clustering of the pellets/briquettes on the hearth due to melting, but also quick reduction of iron oxides by receiving the strong radiation heat in the furnace uniformly. This advantageous feature can also be adopted for recycling of steel mill waste.

The Kakogawa FASTMET ${ }^{\circledR}$ plant are recycling the materials which are difficult to be treated in conventional processes due to high contamination of zinc, and producing the direct reduced iron and the crude zinc oxide. Waste oil is also utilized for the burner fuel at the furnace to reduce the fuelcost.

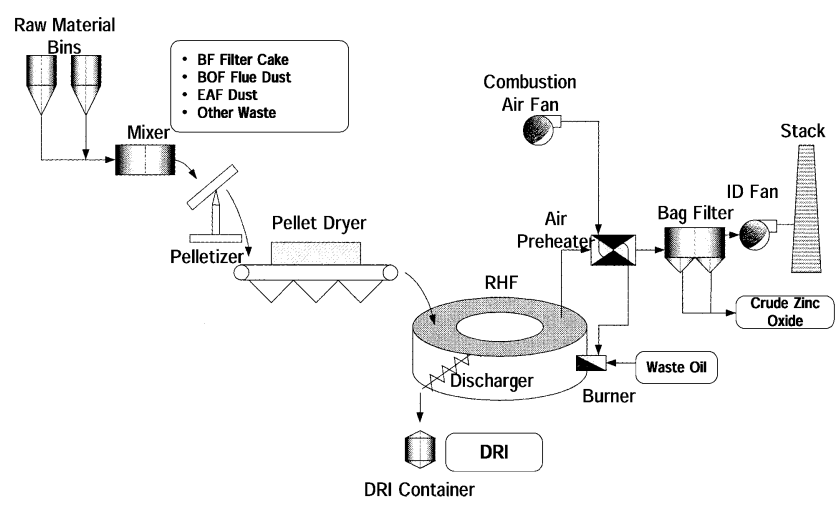

Kakogawa FASTMET ${ }^{\circledR}$ Procss Flowsheet

\section{Steelmaking}

\section{Improvement of Functions of Secondary Refining Equipment}

Nippon Steel Corporation

From the viewpoint of reducing refining cost and improving the cleanliness of high-grade steel, we have tackled the functional improvement of secondary refining equipment.

Recently, Nippon Steel's Nagoya Works has developed a CAS-OB process which can perform refining under reduced pressure, enabling the efficient light-decarburation of low-carbon steel with a simple-structure device. The re- duced-pressure CAS-OB is based on CAS-OB, to which a vacuum pump has been introduced as an exhaust system (Fig. 1). By transferring part of the decarburizing function of the BOF to the reduced-pressure CAS-OB, it has become possible to restrain over-oxidation of molten steel at the last stage of BOF blowing and reduce the refining cost .

On the other hand, Nippon Steel's Muroran Works has developed a ladle-type refining device which adds slag refining function to the existing $\mathrm{RH}$ process. In this system, the lower vessel of the RH degassor is remodeled to have a vacuum-retention lid, thereby transforming the entire ladle into a vacuum system (Fig. 2). The refining by heavy-stirring under vacuum promotes inclusion separation and prevents re-oxidation. The molten steel purification function of the system has successfully integrated and rationalized clean-steel production processes such as LF and RH.

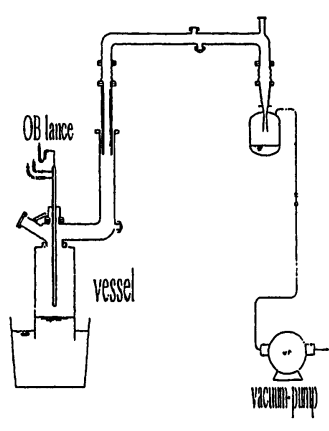

Fig. 1. Outline of the newly remodeled CAS-OB.

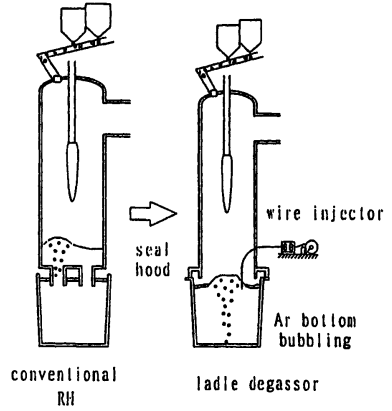

Fig. 2. Feature of the ladle degassor.

\section{Plate}

\section{High Strength Hull Structural Steel Plates for Ultra High Heat Input Welding \\ NKK Corporation}

Container ships have the large hatches that are almost equal to the entire deck space and have fewer bulkhead, in order to increase the cargo capacity and loading efficiency. These structures of container ships require the thicker and higher strength steel plates for upper and side parts of hull structure, hatch side coamings and sheer strakes. Maximum thickness of $65 \mathrm{~mm}$ and yield strength of $390 \mathrm{~N} / \mathrm{mm}^{2}$ steel plates are used in Over Panamax container ships that have more than 4000 TEU (Twenty feet equivalent unit) capacity.

One pass EGW (Electro gas arc welding) is applied for the joining of thicker plate to improve the welding efficiency and the quality of welded joint. In the case of $65 \mathrm{~mm}$ thick plate, the heat input reaches about 400 to $500 \mathrm{~kJ} / \mathrm{cm}$, compared to 100 to $200 \mathrm{~kJ} / \mathrm{cm}$ of multi pass submerged arc welding. This ultra high heat input coarsens the micro structure of HAZ (Heat affected zone) and decreases the HAZ toughness.

NKK developed high strength steel plate suitable for ultra high heat input welding for container ships based on NK-HIWEL technology. This new steel plate improves the HAZ toughness of ultra high heat input welded joint by (1) decreasing alloying elements which are detrimental to 
toughness by using Super-OLAC, the latest accelerated cooling device with highly accurate temperature control and higher cooling rate, and (2) introducing fine grained ferrite micro structure during cooling after welding by applying micro-alloying technology. Figure shows the HAZ toughness of the developed steel. Excellent HAZ toughness are obtained at $-40^{\circ} \mathrm{C}$ as well as $-20^{\circ} \mathrm{C}$.

High strength steel plates for ultra high heat input welding are widely used in Over Panamax container ships and contribute to the shortening of ship building time and the increase in reliability of ship. It is expected that the newly developed steel plate meets the various requirement such as heavier thickness and higher strength under high heat input welding conditions, and extends to the new markets in addition to shipbuilding.

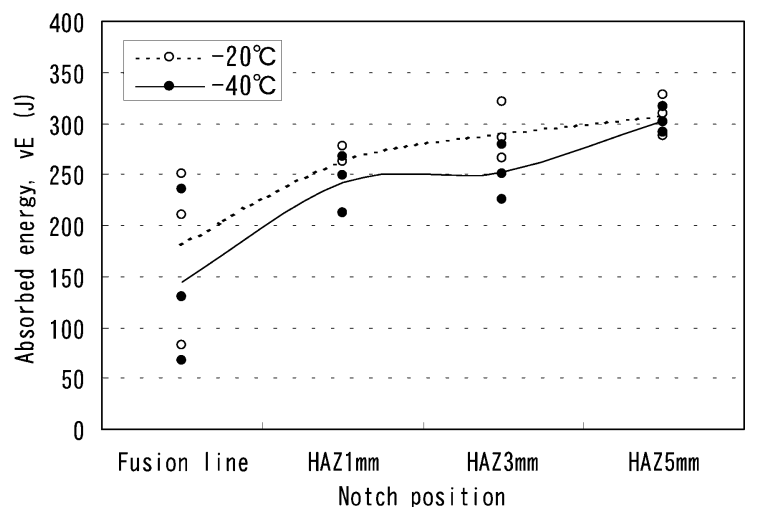

HAZ toughness of one pass EGW joint (Heat input: $430 \mathrm{~kJ} / \mathrm{cm}$, Position: $2 \mathrm{~mm}$ under surface)

\section{Residual Stress Controlled TMCP Steel Plate "HIZUMI-RESU"}

Kobe Steel, Ltd.

A TMCP (Thermo Mechanical Control Process) steel plates, which are excellent in weldability and can be subjected to high efficiency welding with high heat input, have been developed with the growth of the shipbuilding industry.

On the other hand, since TMCP steel plates are produced through controlled rolling and the subsequent accelerated cooling process to control the quality, divergent residual stress distribution due to non-uniform cooling during these processes is occurred. As a result, this can cause a problem of in-plane or out-of-plane deformation and deteriorates working accuracy.

Kobe Steel, Ltd. has developed residual stress controlled TMCP steel plate "HIZUMI-RESU" for use in fabricating the cargo tank and hull structure. It is expected that the use of this new TMCP steel plate will make it possible to build ship block more accurately and to improve the productivity through effective mechanization or automation of production process.

In order to control plate shape and residual stress, a technique consisting of the three stages shown below has been newly established, in which the problems of deformation and shape have been solved.

1) To prevent shape inaccuracy and to minimize the divergent temperature distribution by shape control and scale control during reheating, rolling, and the accelerated cooling process, and consequently to suppress the generation of the residual stress to utmost.

2) To evaluate the shape (deformation) of steel in the asrolled state and after cutting from the residual stress estimated on-line on the basis of the temperature profile in the plate plane after accelerated cooling and, thus, to judge to be shipped or not.

3) As to the steel plates that do not satisfy the level of requirement, to control the residual stress by mechanical method under the conditions determined by calculation based on the estimated residual stress.

A newly developed TMCP steel plate has been used in actual shipbuilding and the amount of product has reached 7000 tones.

The technique to control the plate shape and residual stress can apply all the TMCP steel plates not only for shipbuilding but also for making steel bridges and so on.

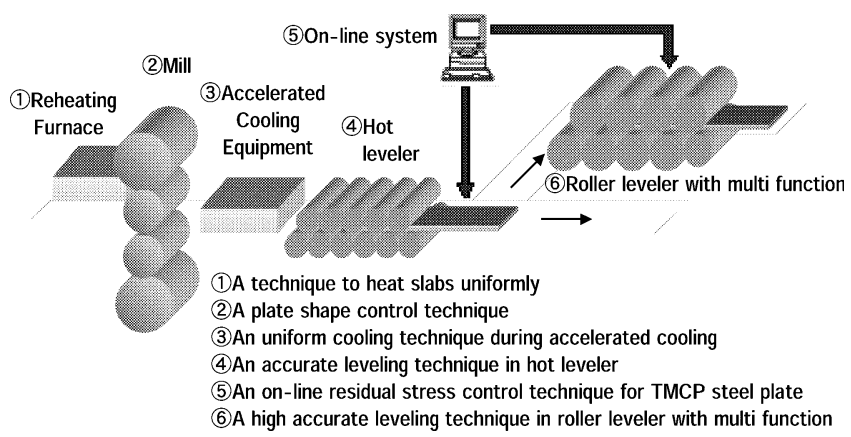

Plate shape and residual stress control techniques for TMCP steel plate

\section{Sheet}

\subsection{Hotrolling}

\section{"NANO HITEN"}

\section{NKK Corporation}

NKK developed ultrahigh formable high strength steel sheet "NANO HITEN" by using fine and homogenized precipitates in a single digit of nanometer (NANO: New Application of Nano Obstacles for dislocation movement). The $780 \mathrm{MPa}$ grade and $980 \mathrm{MPa}$ grade have been developed and they could be applied for automobile chassis parts, for example.

Conventional high formable hot-rolled high strength steel sheets are mainly strengthened by low temperature transformed phase such as bainite and martensite. NANO HITEN, however, is strengthened by the precipitates which are refined to $1 / 10$ in size compared with conventional precipitate strengthening high strength steel sheets. This refinement is obtained by the combination of additional elements and hot-rolling condition. The refined precipitates remarkably improved the strength of steel because the number of precipitates increases dramatically with decreasing the diameter of the precipitates. For example, if the diameter is assumed to become $1 / 10$, the number of precipitates increases 1000 times larger in the same steel composition. As described above, the remarkable precipitate strengthening by fine precipitates is the essence of NANO HITEN. 
NANO HITEN has a ultrahigh formability since it is strengthened by fine and homogenized precipitates. For example, $780 \mathrm{MPa}$ grade NANO HITEN shows 1.3 times or more elongation and hole-expanding ratio compared with conventional high formable high strength steel sheet. Moreover, strength of NANO HITEN is very stable in mass production such that the distribution of strength is less than a half against the conventional steel. The other remarkable property of NANO HITEN is the low flow stress at hotrolling process. Therefore thinner sheet and wider sheet can be provided in NANO HITEN series. In $780 \mathrm{MPa}$ grade, the steel sheet with thickness of $1.2 \mathrm{~mm}$ can be provided and the applicable maximum width increases more than $40 \%$ in the thickness of $1.8 \mathrm{~mm}$.

NANO HITEN is also good at Zinc plaiting, so galvannealed hot-rolled sheet is one of applications in NANO HITEN series.
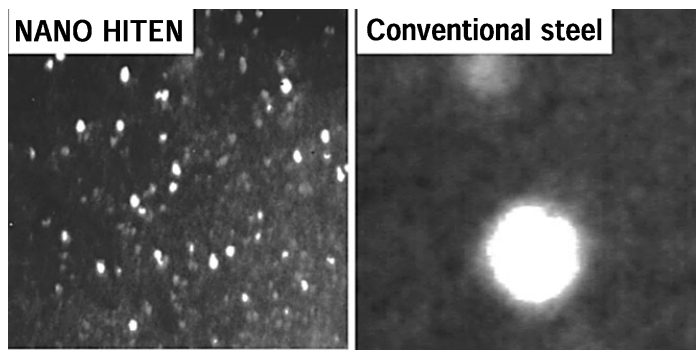

$20 \mathrm{~nm}$

Precipitates in NANO HITEN

\section{Ultra Fine Grain Steel at Nakayama Hot Strip and Plate Mill}

Nakayama Steel Works, Ltd.

The world's first Ultra Fine Grain Steel production in a hot strip mill on commercial base has succeeded at Nakayama hot strip mill. The steel is manufactured by high reduction and strong cooling just after rolling one after the other. The average ferrite grain size of Ultra Fine Grain Steel is about $2-5 \mu \mathrm{m}$. It is too small compared with the conventional grain size of $10-20 \mu \mathrm{m}$. Nakayama hot strip Mill is equipped with all the world's newest technologies for excellent product quality and the production of Ultra Fine Grain Steel. In January 2001 we started rolling Ultra Fine Grain Steel for trial and since December 2001 we have commercialized NFG500 of TS $500 \mathrm{MPa}$-grade and NFG600 of TS $600 \mathrm{MPa}$-grade. NFG means Nakayama Fine Grain. Nakayama Fine Grain Steel is rolled by high reduction more than $50 \%$ at latter three stands and is cooled strongly about $30 \mathrm{~K}$ per one stand. The SRDD rolling, or the Single Roll Drive With Different Diameter is provided on stands F4 through F6. The SRDD rolling consists of large driven bottom work roll and small non-driven top work roll. Due to the effect of small equivalent roll diameter and the effect of shearing forced in the area caused by non-driven top roll, the rolling force is reduced by about $20 \%$. These effects make it possible to perform high reduction rolling of over $50 \%$ reduction ratio. The high flow rate curtain wall cooling system is installed between the latter three stands and at the delivery of the last stand. It can pre- vent the grain growth and control the finishing temperature. The properties of Ultra Fine Grain Steel by making the ferrite grain size finer are high tensile strength, high yield point, high toughness, good formability, good weldability and high fatigue limit. Related to the development of NFG, 4 patents (including 1 foreign patent) are approved and 9 patents (including 8 foreign patents) are applied for. Nakayama Fine Grain Steel meets customer's needs to attain lighter weight and to simplify or cut down manufacturing process. We will apply this steel to the reduction of fuel consumption by lighting of automotive weight.

Curtain Wall Cooling

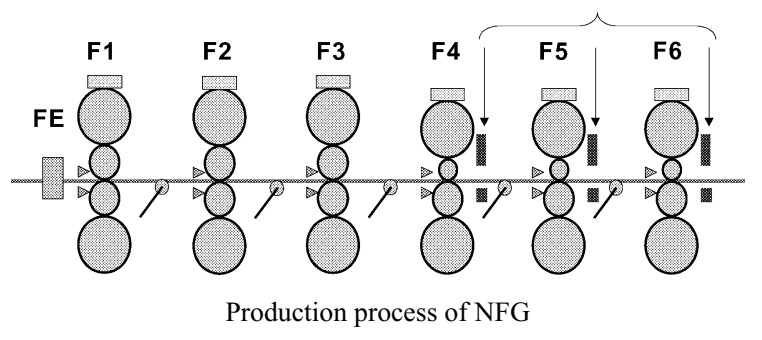

NFG

Conventional steel
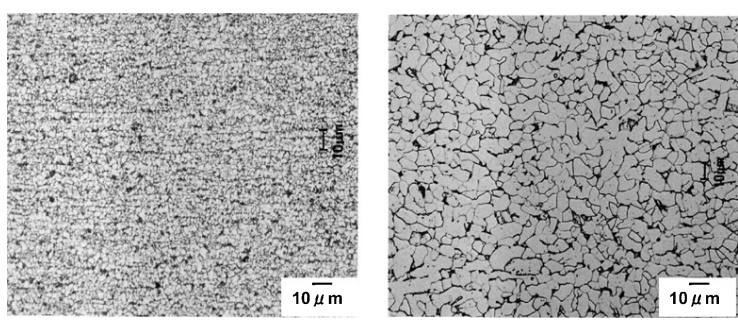

Microstructure of NFG

\subsection{Surface Treatment}

\section{"TOUGH-ZINC Hyper"}

\section{Sumitomo Metal Industries, Ltd.}

Sumitomo Metal Industries, Ltd. had succeeded to develop and sell a new hot-dip galvanized sheet steel, named "TOUGH-ZINC Hyper", with the surface quality remarkably superior to their conventional product "TOUGH-ZINC".

The key technology of the present development is the special flattening treatment in galvanizing process, which reduces remarkably the dross defect and ripple mark on the surface. The new product exhibits smooth and uniform surface quality and is suitable for the exterior of electrical home appliance and IT appliance, and the automotive exposed application. The product with Chromium-free passivation, named "TOUGH-ZINC Hyper NEO (New

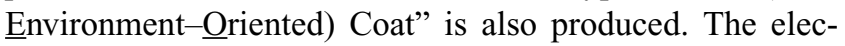
tric customers had already adopted this ECO-product.

\section{Others}

\section{Linux OS PC Used for the First Time to Control Continuous Galvanizing Line in Japan NKK Corporation}

NKK has become the first steelmaker in Japan to adopt a general-purpose PC system with the Linux operating sys- 
tem (OS) as a process control computer (PCC) at one of its plant facilities. The system is now used for the No. 3 hotdip continuous galvanizing line of NKK Steel Strip \& Sheet Corp. at the Keihin Works.

Because the PCC is required to process external signal input and output information from sensors at high speed, in real time, and with high reliability for 24-hour continuous operation, expensive special-purpose computers from limited manufacturers had been adopted previously.

In order to generalize and standardize PCCs and achieve cost reductions, NKK conducted a radical review of its PCC system configuration by fully utilizing the latest information technology. Consequently, it was decided to adopt Linux PCs as PCCs throughout the company. Specifically, to achieve real-time processing using Linux PC for task, input/output and file management, NKK developed its own application software for control support. In addition, process input/output functions were separated from the PC itself by use of a general-purpose sequencer instead. The PCC and sequencers are linked by a general-purpose network (Ethernet).

By adopting such an open PCC system with Linux and control support software, system construction expenses have been cut by over $40 \%$ compared to the previous system. Also, future system replacement will be possible simply by upgrading the PC, instead of replacing the entire system of hardware and software as before, allowing speedy, low-cost replacement.

The new system is scheduled for adoption for other production lines at both the Keihin and Fukuyama Works.

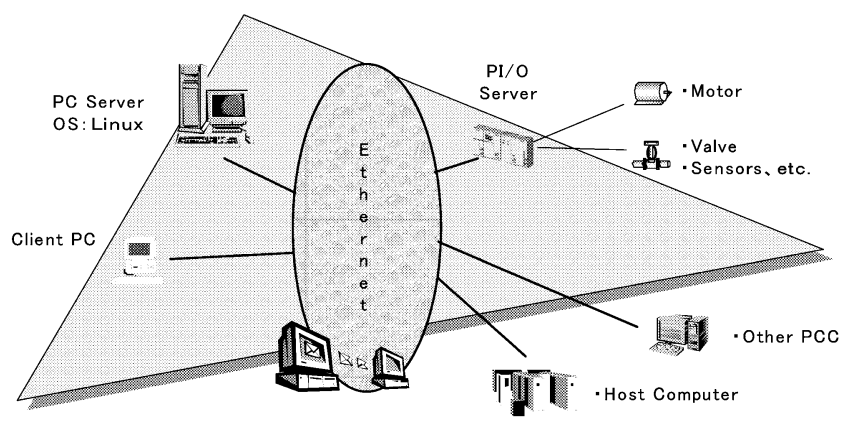

Process control computer system configuration

\section{NKK's DME Direct Synthesis Technology NKK Corporation}

NKK began work on technology to produce DME directly from carbon monoxide and hydrogen in 1989 for the purpose of utilization of steel producing by-product gas. In October 1999 an NKK-led team achieved a world first record in synthesizing DME from coalmine gas (coal-bed methane) by using a five-ton-per-day large scale bench plant. This development verified the possibility of large- scale, low-cost synthesis of DME as a clean and easilyhandled fuel for practical use.

In NKK's new DME synthesis technology, a gas comprised primarily of carbon monoxide and hydrogen is derived from coal-bed methane. This gas is then used for direct synthesis of DME in a slurry-bed reactor that uses a newly developed catalyst.

In addition to coalmine gas, this process can be applied to natural gas, associated gas, and gas from coal gasification. This technology is expected to contribute greatly to solve the global energy problem and prevent global warming in the 21 st century.

Much is expected of DME as a motor vehicle fuel with low environmental load other than the fuels for power generation and household uses. DME has no carbon-carbon bonding and its combustion therefore does not produce black smoke. As it contains no sulfur, $\mathrm{SO}_{x}$ is not generated, nor is particulate matter derived from sulfur compounds. In 1998, NKK succeeded in testing a commercially available diesel engine truck running on DME. Tests showed that no diesel smoke was emitted, and that there did not exist any problems with starting, accelerating, stopping, and other performance of the vehicle. Fuel consumption was similar to an engine running on diesel fuel (gas oil) in terms of energy equivalent.

Now, NKK-led team began to develop a conceptual design for a proposed 100-ton-per-day pilot plant and also jointly established DME commercialization research company as several thousands-per-day production plant for aiming commercial DME utilization can get under way as quickly as possible.

NKK's direct DME synthesis technology can produce DME from various raw materials such as steel producing by-product gas, gasification of waste and plastic, methane from fermentation of sewage and animal excrement. It will contribute, therefore, not only in supplying clean energy but also forming the society of resource recycling.

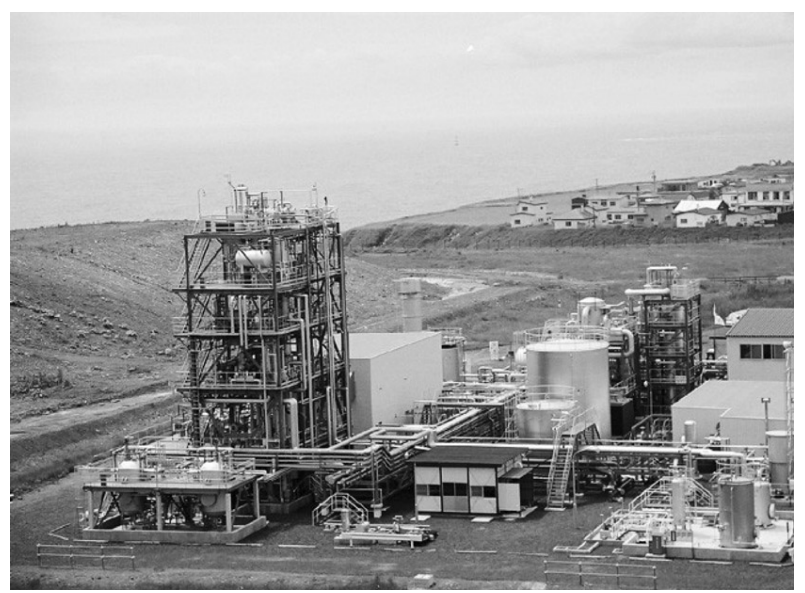

DME large scale bench plant: 5 ton/day 